\title{
An Evaluation of Aesthetic Attractiveness from the Tourists' Viewpoints Based on the Used Techniques in Persepolis Site Museum
}

Maryam Shirvani ${ }^{1^{*}}$

Hossein Ahmadi 2

\section{Rasool Vatandoust ${ }^{3}$}

1*Phd candidate, Art University of Isfahan, Isfahan, Iran, Corresponding Author Email: m.shirvani83@gmail.com ${ }^{2}$ Associate professor, Art university of Isfahan, Isfahan, Iran ${ }^{3}$ Assistant professor, Azad University of Tehran, Tehran, Iran

Doi:10.5901/mjss.2016.v7n5p278

\begin{abstract}
Persepolis site museum is one of the most important places in the field of tourism in Iran, which is in the list of UNESCO World Heritage and attracts many visitors from around the world every year. Therefore, making this complex attractive by means of various methods is very important. Hence, different techniques have been applied to make the complex more attractive and they are studied in this work. The main objective was to find a significant relationship between conveying the aesthetic value from the viewpoint of the audience through the techniques applied to convey the historical, visual, preserving and social values. In this regard, according to the results and variables of the study, some questionnaires were developed using the Likert Scale and were distributed among 400 visitors. This research is both quantitative and qualitative. Through the qualitative method the techniques applied to convey the values were assessed while through the quantitative method the SPSS software was used for inferential analysis of the variables and the Pearson correlation test and ANOVA were also used. The obtained results indicate that the techniques applied to convey the historical and visual values have a direct relationship with the aesthetic value. In addition, there is a reverse relationship between preservation methods and the aesthetic value, and the relationship between social value and aesthetic value is not significant. Accordingly, it might be said that aesthetically, the historical value and the originality which have caused the presence of visitors are hidden in Persepolis site museum and the applied techniques have not worked well.
\end{abstract}

Keywords: tourist, making attractive, aesthetics, site museum, Persepolis

\section{Introduction}

The concept of heritage widely includes definitions of values with which they are associated (Hall \& McArthur, 1993; Lowenthal, 2005). Prentice believes that heritage may specifically include landscapes, buildings, artistic crafts, cultural traditions, etc that will be very important for future generations (Prentice, 1993:3). But historical sites especially site museums are defined symbolically and include humans (people), culture and the relationship between them (Hall \& McArthur, 1993:8). Touristic sites cause a critical and important relationship between historical heritage and visitors for several reasons. Firstly, historical sites are now considered as the most important tourist destinations (Ayala, 1998). Second, the income from tourists visiting historical sites is one of the main sources for maintaining these sites (Ayala, 1998; Van Oosterzee, 2000). even though the great number of visitors may specifically be considered as a serious threat to historical sites.

Regarding the importance of creating attraction in the audiences in visiting historical sites, one of the issues that could be considered in tourism and preservation of cultural heritage discussion is the recognition of effective value components along with the attractiveness issue (Vestheim et al,2001; Avrami et al,2000). In value-based preservation, the approach is that the values with an effect on the audience's view should be evaluated (Munos Vinos,2005:22) and used to improve the attractiveness (Shiraziyan,2013). Today, prevention of the values is one of the important principles in the field of introducing heritage works (Sun Hua,2010:6957) which can have an indispensable role in the life of a historical monument.

Hence, what is important in regards with values in historical monuments is the quality and assessment of their values according to environmental conservation and audiences (Shiraziyan,2013:59) and in conservation of cultural heritage, creation of attraction through expressing the relationships of monuments values for the audience is one of the main approaches. 


\subsection{Review of Literature}

However, the values related to a heritage work include different classes of cultural, historical, social, mental, ... values. Therefore, providing the relationship between effective value factors in sites and making attraction which tie to aesthetic values of a monument can have effective roles on the presence of tourists in heritage sites. Taking into consideration the preservation issue based on knowledge and taking into consideration the value components were first introduced in the world as the UNESCO statement was published in 1972. Thereafter, with the initial release of Burra charter (1981) the evaluation of effective factors in value preservation were considered. Since then, the necessity of considering effective concepts on preservation based on value components has been emphasized in various rules, statements and charters (ICOMOS New Zealand, 1993; NARA, 1994; Sant Antonio, 1996; Final Burra Charter, 1999; Mexico City Statement, 2003; ICOMOS Charter, 2008).

So far, different studies have been carried out on the techniques of historical sites to find the audience satisfection. Helen Hasen(2009) is one of the researchers who has done many studies on historic tourist parks. Also, Rendall Mason (2002) analyzed monuments characteristics in order to introduce conservation strategies and his model is of utmost importance in managment plans (Figure1). Therefore, it is tried to use his model in the present study. However, despite the value characteristics in attraction and conservation which are studied in different countries, they are not studied in Iran and restoration of a monument is just considered to show attraction. Hence, this study tries to analyze conservation approaches with respect to value features of Persepolis site museum.

Recognition and analysis of value features in heritage monuments are absolute characteristics in their preservation which can be studied in different parts of objects, buildings, sites, historical site museums, etc. In this regard, site museums have special ranks in attraction and conservation issues because of their unique features such as simaltaneous depiction of the monuments and the audiences touch with its creation.

But the interest in site museums started in 1960s and developed specifically in the world of museums from late 1970s. Afterwards, different types of site museums were gradually classified and their goals were determined. The site museums and historic eras covering them were studied by ICMAH Institute and they were evaluated by the ICOM Institute in 1995 (Erturk, 2006:338). A site museum is defined as a type of museum that preserves the findings of different years and displays them in original locations (Deladelle, 2001:10). The idea of site museum is to make a direct relationship between visitors and the formation of artifacts where the visitors visit the explored objects and the historical site at the same time. In addition to visiting historical artifacts, visitors to site museums would be directed to see archaeological activities as well as executive preserving and restoration operations in the historical sites. Hence, their perception of a historical site would not only be watching historical objects, but a comprehensive training would be followed for them. Today in developed countries, in the field of cultural heritage and tourism, creating site museums is prior to expanding classic museums due to public acceptance and leaving great impacts on the growth and development of the area in a short time (Heidari \& saatiean, 2011:32).

Regarding site museums, the issue of preservation and value components along with the audience gets important because generally, the base of site museum formation is the mutual cooperation of the audience and the historical artifacts (Heidari \& saatiean, 2011:35). Among the audience and the artifacts, the issue of aesthetic value has a special importance. Because visual and aesthetic factors are the first ones in attraction creation. Other techniques can be studied and be evaluated in other to express these factors. Due to the presence of the artifacts in the context of creation (Erturk, 2006:343), the attractiveness concept can be investigated better and concretely among the audience in a site museum.

The attractiveness concept has a direct relationship with axiology of the artifacts (Sun Hua, 2010:6959). Therefore, it can be seen that the main objective of creating site museums is to make the audience familiar with the history and formation of nations and to know cultural heritage and works in the context of their creation. Hence, an important goal in this field will be attractiveness and stating the aesthetic value so that the audience gets interested in visiting the historical site. 


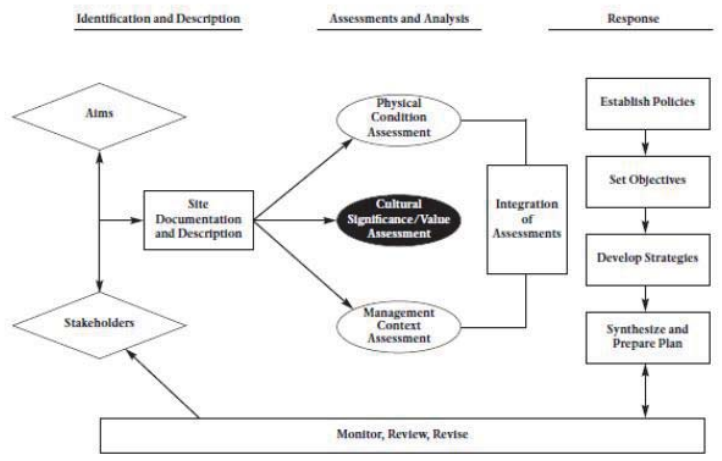

Figure 1: Methodology of analyzed monuments characteristics (Specially Value) in order to introduce conservation strategies, Rendall Mason (2002)

\subsection{The study:}

In Iran, there are various historical sites which are of importance with regard to the study of the audiences' viewpoints in expressing values and attraction. Persepolis is one of the most important monuments of the Achaemenid Empire constructed in $518 \mathrm{BC}$ and according to the archaeological studies, its construction never completed and it failed to live after Alexander the Great assaulted there (Amiryegane \& Nafisi,2003:25). The work was registered in 1979 to No. 114 UNESCO list and it is now one of the major tourism destinations in Iran. Studying and identifying value concepts related to attractiveness and aesthetic value in this complex will help to obtain useful results associated with tourism and tourist attraction as well as meeting the tourists' needs during their visit (Picture1 \& 2).

Picture 1: Persepolis Site Museum
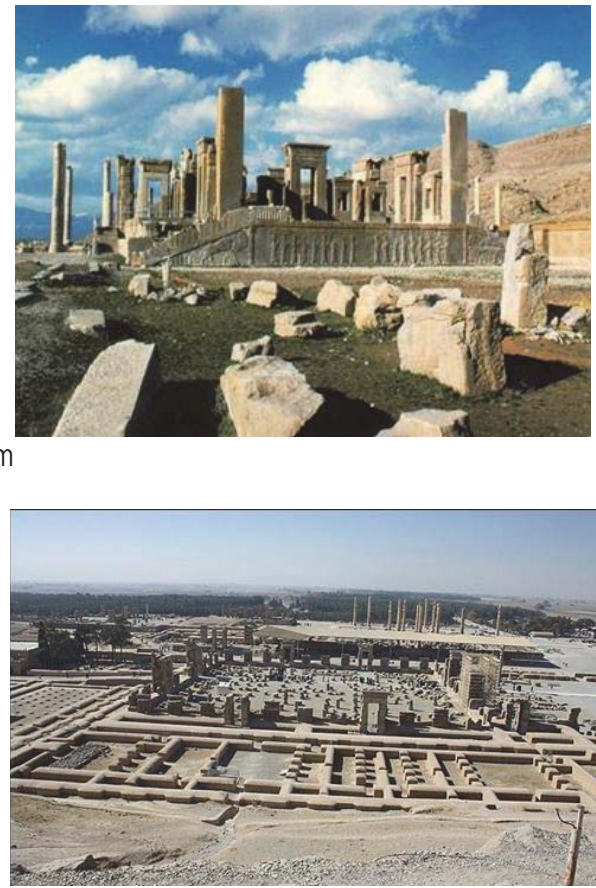

Picture 2: Persepolis Site Museum 


\section{Objectives and Methodology}

\subsection{Objectives}

In Iran, Persepolis site as a World Heritage area is of great value. Therefore, investigating value-identification discussions will be very significant for its attractiveness in terms of tourism and developing tourism industry. Hence, the aim of this study is to find the relationship between aesthetic attractiveness associated to value components in Persepolis site museum. So, the main question is that how value components can show themselves along with aesthetic attractiveness concepts? And what factors make the tourists interested in attending and spending time in this museum site based on value components and attractiveness? It seems that the techniques applied in a site to indicate different values have an impact on attractiveness among the audience. Measuring it by the audience as an integral member of a historical site will play an important role in the expression of a successful performance in terms of historical site preservation management. The hypothesis is that there is a significant relationship between the expression of aesthetic value from the audiences' perspective and the techniques applied to express historical, visual, preservative and social values.

In indexication of the under study variables on the aesthetic attractiveness, the specified techniques in the complex which were assessed important in the feild have been analyzed. As there are various values with respect to site museums and creatin of attraction in them, these four cases have been selected due to the monuments' sociohistorical characteristics in Iranian culture. In the proposed hypotheses, it has been tried to not only measure the audiences' satisfaction with the applied techniques in various value discussions and its effect on attractiveness of the sites, but also to evaluate the significant relationships between the discussions on historical, preservative, visual and social values by the applied techniques and the discussion on aesthetics from the audiences' perspective. In this regard, the effect of the audiences' ages on the creation of this significant relationship has been investigated.

\subsection{Methodology}

For the aim of the study, the research has been carried out in the three phases of knowledge, evaluation, and analysis. The methodology used in this study is an applied one with respect to its aim, a field one with respect to the level and variables control, and an analytical one with respect to information process. Also, it benefits from both quantitative and qualitative methods. In the quantitative one, variables control and the effective concepts in expressing attraction in sites are introduced in Table 1.

Next, to measure the visitors' satisfaction with attractiveness issues based on preserving and identifying value components that affect attractiveness in the quantitative method, some enclosed questionnaires were prepared based on the variables under study and they were distributed among 400 visitors. The questions scale was selected to be spectral (attitude detector) and the Likert Scale was used to prepare the questionnaires. Using SPSS software, we did the inferential analysis of historical, preservative, social and visual value variables based on the applied techniques related to attractiveness and aesthetic value of the monument. To test the hypotheses, Pearson Correlation Coefficient was used and to investigate the significant relationship between the visitors' ages and the aesthetic value expression related to the variables assessment, the ANOVA test was used.

Table 1: Analysis of the activities carried out by making Persepolis sites Museum attractive

\begin{tabular}{|l|l|}
\hline Topics attractiveness and value & Activities \\
\hline Historical value and attractivness & $\begin{array}{l}\text { Use tour guides (Hazen2009. Huh \& Uysal 2004). } \\
\text { Introducing bases Persepolis at the entrance (Hazen 2009) } \\
\text { Help boards and comment in the section (Shiraziyan 3013) }\end{array}$ \\
\hline $\begin{array}{l}\text { Conservation methods and } \\
\text { attractivness }\end{array}$ & $\begin{array}{l}\text { Protective operations in workshops in the area of the site museum (Heidari \& Saatiean 2011). } \\
\text { The relationship between visitors to conservator the campus shop (Munos Vinas 2005) } \\
\text { Landscaping between the site and the area and facilitating visits (Shiraziyan 3013) } \\
\text { Creation of database protection for professionals (Heidari \& Saatiean 2011). }\end{array}$ \\
\hline Visual value and attractivness & $\begin{array}{l}\text { Design open air museum collections (Designing of drilling) (Hazen 2009, Deladelle 2001) } \\
\text { The use of modeling (Made immortal army soldiers tiling) (Shiraziyan 3013) } \\
\text { Use proper lighting (Deladelle 2001) }\end{array}$ \\
\hline Social value and attractivness & $\begin{array}{l}\text { The use of special light and sound (Hazen2009. Huh \& Uysal 2004) } \\
\text { Holding the Noroze symbolic ceremony in site } \\
\text { Political developments have been introduced in the form of a film set at the entrance (Heidari \& } \\
\text { Saatiean 2011) }\end{array}$ \\
\hline
\end{tabular}




\section{Analysis of the Data}

\subsection{Values in Tourism Development among Irans Historical Site Museums}

In today's world, tourism industry has had a high level of economic development in most countries of the world and it is considered as a part of economic bases in countries (Regidor,2009:1). Meanwhile, it is the feature(s) of destination tourism resources that direct people towards the destination to do tourism activities. These resources include natural, cultural, events, tourism activities, and service resources (Salehi \& Hassanpour,2012:97). Hence, cultural and historical resources can play an important role in the development of tourism industry (Hazen, 2009:168).

Achieving the concepts that make these resources attractive can also play an important role in the development of this industry (Shiraziyan,2013:34). The value identification issues regarding the preservation of historical monuments and sites are among very important issues on the attractiveness of a monument (Vestheim et al,2001; Avrami et al, 2000). Regarding value preservation, it is believed that the values that a monument has from the viewpoint of the audience have to be evaluated (Avrami et al,2000:12) and one way to make it attractive is to used these values differently in a space (Shiraziyan,2013). One main issue on tourism in Iran and some countries is the disability to provide attractiveness and presence of the audience in a historical place (Shiraziyan, 2013). Many of historical and cultural works are taken into consideration just because of having ancientness value (Hojjat, 2001:134) and this implies the lack of ability and accuracy in terms of attractiveness and the values considered by the audience even though the existence of different values makes it possible for historical monument tourism to justify the audience to spend money on visiting (Hazen, 2009:170) and preserving them.

Attractiveness is considered as the main factor to enter the work to the economic cycle on the one hand and to preserve it on the other hand (Fyall \& Rakic, 2006:16). So, a monument's location attractiveness might increase or decrease with or without human intervention because the values of historical monuments or the audience reception of the values increase or decrease over time and due to various reasons. But by investigating visual and preservative attractiveness, researchers have found that the type of preservation has great impacts on individuals' personal concept of aesthetics (Wang et al, 2008:212).

The values related to World Heritage sites have been published by the International Association of World Heritage, UNESCO and the World Conservation Union. The most important values mentioned in this context are as follows: (1) aesthetic, (2) cultural, (3) environmental, (4) preservative and educational, (5) economic, (6) symbolic an mental, and (7) social-political values. The main idea of the World Association is that heritage is vulnerable and they must be preserved for future generations and they are impossible to be repeated (Hazen,2009).

Benefiting from appropriate techniques and methods in conservation and managment plans in historical site museums can be very effective in creation of attraction and expressing different values. Consistent analysis of this process in sites can help the existence of the monument in the present time.

\subsection{The Relationship between the Audience, Value and Attractiveness in Persepolis Site Museum}

Audience has always been an integral part of museum sites; therefore, taking its position and role into consideration is very important. It is critical to identify the factors influencing attractiveness of a site and affect the audience to attend there. In addition, how to create attractiveness is of great importance. Tourism is an immutable social, human, economic and cultural fact. The impact of tourism on historic monuments and sites is of particular importance and can even be increased due to known conditions of developing this process. Tourism is one of the phenomena that will leave the greatest impacts on human environment in its general sense and on the monuments in its specific sense (Feilden \& Jokilehto, 2003:180). Today, making appropriate balance between considering the tourism and preserving historical sites is really important (Huh \& Uysal, 2004:180). Consequently, the most effective way to preserve the World Heritage values in certain areas must be based on research and recognition of visitors' characteristics (Fyall \& Rakic, 2006:161). There are various types of visitors in historical areas. Any effective preservation of the sites requires some knowledge and awareness originated from the visitors' tendency and interest in special things (Moscardo et al, 2001:22). Having primary focus on visitors of the sites will make it possible to acquire some partial knowledge of the needs of visitors and World Heritage sites. The variety and difference between sites and visitors have raised challenges in presenting the values in order to respond the conservation of World Heritage sites in countries (Bandarin, 2005). Hence, knowing the audiences and their needs at the time of visit as well as the factors that make a site attractive is very important. By recognizing these factors and applying them to attractiveness, it can be expected that the audience spend more time and money on visiting the site. On this basis, it can be said that different methods based on the needs of visitors as well as the introduced 
values will be important and effective variables in attractiveness.

Persepolis is one of the significant and important relics of the Achaemenid in Iran. It is located in Fars province and near Marvdasht city on the slopes of Mount Rahmat. This monument includes the Achaemenid Empire palaces and a ceremonial center of that time where grand ceremonies had been held in springs. Regarding the structure, most parts of it have come out of the soil and some parts of Parseh City around the complex are getting drilled. Therefore, it is a very large collection of historical monuments that not only contains archaeological findings but also includes a cultural perspective. Persepolis site includes architectural structures, objects, graves, archaeological works, etc that have been introduced together as a museum site. This huge monument attracts numerous visitors annually from foreign countries and domestic cities in Iran and it is one of the most important areas in the tourism sector.

In order to reach the aim of the study and analyze the audiences viewpoints in attraction creation, a series of questionnaires were designed according to the aforementioned variables and were given to the audiences. Below, the age and gender distribution table is shown(Table 2).

Table 2: Aged people in research

\begin{tabular}{|l|c|c|c|c|c|c|c|}
\hline Sex & Number & $18-25$ years & $26-35$ years & $36-45$ years & $46-55$ years & $56-65$ years & After 65 years \\
\hline Male & 218 & 34 & 64 & 58 & 38 & 18 & 6 \\
\hline Female & 182 & 53 & 58 & 35 & 22 & 10 & 4 \\
\hline
\end{tabular}

One of the hypotheses that were made in the beginning was on this basis that there was a significant relationship between the age of the visitors and their satisfaction with the aesthetic value of the monument. To test the hypothesis, ANOVA was used. Using this test, we investigated whether there was a significant difference of aesthetic value between various age groups at the significance level $p>.05$. Therefore, no significant difference was seen between groups at the significance level $p>.05$ in terms of aesthetic value.

Next, the visitors were asked questions such as "What features of the site have caused you to select it for visiting?" and "How important is to preserve the site based on the values from your viewpoint?". Results have been shown in table 3.

Table 3. Visitor agreement with statements related to the value of protected areas.

\begin{tabular}{|l|c|c|c|c|}
\hline \multirow{2}{*}{ Question } & \multicolumn{2}{|c|}{ yes } & \multicolumn{2}{c|}{ No } \\
\cline { 2 - 5 } & Male & Female & Male & Female \\
\hline The historical environment of this place is very valuable & 214 & 174 & 4 & 8 \\
\hline This place is important because of its cultural value & 175 & 170 & 43 & 12 \\
\hline This place is one of the 'wonders of the world' & 208 & 163 & 10 & 19 \\
\hline This place is socity important & 162 & 87 & 56 & 95 \\
\hline This place could easily be damaged & 119 & 134 & 99 & 48 \\
\hline This place is important because it has Aesthetic value & 185 & 161 & 33 & 21 \\
\hline This place is economic important & 135 & 93 & 83 & 89 \\
\hline We have a responsibility to our children to protect this place & 210 & 182 & 8 & 0 \\
\hline
\end{tabular}

\subsubsection{The expression of historical value through applying the techniques of aesthetic attractiveness}

The question asked in terms of the historical value and the techniques of attractiveness applied to Persepolis Site Museum was as follows: Taking into consideration the installed elements and the guidance of the tourist guides and also what is seen at the entrance of the site, how much could you recognize the historical value to visit the site? Findings show that the applied techniques have been able to make visitors desirably satisfied. This has been true for both groups of visitors. About $43 / 25 \%$ were extremely satisfied, $22 / 75 \%$ were very satisfied, and $21 / 75 \%$ were fairly satisfied. A few visitors were dissatisfied with the applied techniques and this implies that the site has been successful in terms of creating attractiveness by expressing the historical value (Table 4).

In order to prove the hypothesis on finding a significant relationship between satisfaction with the techniques of expressing historical value and aesthetic attractiveness, Pearson Correlation and Regression were used. As the significance level is lower than 0/05 it can be concluded that the relationship between the expressed techniques of historical and aesthetic values is significant. Pearson Correlation Coefficient shows the intensity of this reaction as 0/63. Since this coefficient is positive, it is said that the relationship between historical and aesthetic values is direct (Tables 5 and 6). 


\subsubsection{The condition of applied preservations in aesthetic attractiveness}

This section deals with the applied preservations in the complex and the techniques used to create attractiveness for the audience. The questions were designed based on the activities done in terms of the relationship between the visitors and the preservation experts and active workshops at the site. The satisfaction was average in this regard. About $33 \%$ were dissatisfied with the techniques, $45 \%$ were very satisfied and $22 / 25 \%$ were average and it was hoped that better situations would be provided (Table 4).

In the next stage, to prove the hypothesis on finding a significant relationship between satisfaction with the applied preservations and expression of aesthetics, Pearson Correlation and Regression were used. As the significance level is lower than 0/05 it can be concluded that the relationship between the preservative and aesthetic values is significant. Pearson Correlation Coefficient shows the intensity of this reaction as $-0 / 58$.

Since this coefficient is negative, it is said that the relationship between preservative and aesthetic values is reverse (Tables 5 and 6).

\subsubsection{Visual properties and aesthetic value of the site for creating attractiveness}

Expressing aesthetic and visual values is a key factor in creating attractiveness in a historical site. In this section, the questions were designed based on the techniques provided to create visual attractiveness (design of the museum, lighting, etc) in the complex. Results of the surveys suggest that the satisfaction was remarkable. $33 \%$ were extremely satisfied with the applied techniques, $27 \%$ were very satisfied and $22 / 25 \%$ were average. $17 / 75 \%$ were not satisfied with the applied techniques. Fortunately, according to these results, it can be said that the visual and aesthetic values in this museum site have been synchronous with the applied techniques and have satisfied the audience (Table 4).

In the next stage, to prove the hypothesis on finding a significant relationship between satisfaction with the applied visual values and expression of aesthetics, Pearson Correlation and Regression were used. As the significance level is lower than 0/05 it can be concluded that the relationship between the visual and aesthetic values is significant. Pearson Correlation Coefficient shows the intensity of this reaction as $0 / 58$.

Since this coefficient is positive, it is said that the relationship between visual and aesthetic values is reverse (Tables 5 and 6).

\subsubsection{Expression of social values and aesthetic attractiveness of the site}

Historic and social transformations during history may be considered as an important factor to create attractiveness in a monument. Expressing these transformations by using appropriate techniques in this field will be really effective. On this basis, the visitors were asked questions about using the techniques and special symbolic ceremonies (lighting and acoustic, singing Norouz songs, etc) to express the social value of the monument at the time of its life. About $3 / 75 \%$ were extremely satisfied with the applied techniques, $6 / 75 \%$ were very satisfied and $8 / 25 \%$ were average. $46 / 25 \%$ were a little satisfied with this process while $35 \%$ were almost not satisfied. Unfortunately, results show that the techniques applied to create attractiveness could not appropriately satisfy the visitors and more appropriate measures have to be thought for such a splendid and valuable monument (Table 4).

In the next stage, to prove the hypothesis on finding a significant relationship between satisfaction with the expression of social value with the applied techniques and the expression of aesthetics, Pearson Correlation and Regression were used. As the significance level is higher than 0/05 it can be concluded that the relationship between the social and aesthetic values is not significant (Tables 5 and 6).

Table 4: The frequency distribution of the values and techniques used in creating attractiveness

\begin{tabular}{|l|c|c|c|c|c|c|c|c|c|c|}
\hline & \multicolumn{2}{|c|}{ Alot } & \multicolumn{2}{c|}{ Much } & \multicolumn{2}{c|}{ Medim } & \multicolumn{3}{c|}{ Little } & \multicolumn{2}{c|}{ Very Little } \\
\hline & Frequency & Percentage & Frequency & Percentage & Frequency & Percentage & Frequency & Percentage & Frequency & Percentage \\
\hline $\begin{array}{l}\text { Historical value and } \\
\text { attractiveness }\end{array}$ & 173 & $43 / 25$ & 91 & $22 / 75$ & 87 & $21 / 75$ & 34 & $8 / 5$ & 15 & $3 / 75$ \\
\hline $\begin{array}{l}\text { Conservation value } \\
\text { and attractiveness }\end{array}$ & 93 & $23 / 25$ & 87 & $21 / 75$ & 89 & $22 / 25$ & 69 & $17 / 25$ & 62 & $15 / 5$ \\
\hline $\begin{array}{l}\text { visual value and } \\
\text { attractiveness }\end{array}$ & 132 & 33 & 108 & 27 & 89 & $22 / 25$ & 42 & $10 / 5$ & 29 & $7 / 25$ \\
\hline $\begin{array}{l}\text { Social value and } \\
\text { attractiveness }\end{array}$ & 15 & $3 / 75$ & 27 & $6 / 75$ & 33 & $8 / 25$ & 185 & $46 / 25$ & 140 & 35 \\
\hline
\end{tabular}


Table 5: Pearson correlation test

\begin{tabular}{|l|c|c|c|}
\hline Index - Items & The correlation coefficient & Significant level (two-tailed) & Number \\
\hline Historical value and aesthetic & 0.63 & 0.00 & 400 \\
\hline Conservation value and aesthetic & -0.58 & 0.00 & 400 \\
\hline visual value and aesthetic & 0.54 & 0.00 & 400 \\
\hline Social value and aesthetic & 0.12 & 0.23 & 400 \\
\hline
\end{tabular}

Table 6: Simultaneous regression values

\begin{tabular}{|l|c|c|c|c|c|c|}
\hline Items & The regression coefficient $(\mathrm{B})$ & $\mathrm{SE}$ & Standard rate $(\beta)$ & $\mathrm{t}$ & Deal $\mathrm{R}^{2}$ & Deal $-\mathrm{P}$ \\
\hline Historical value & $0 / 474$ & $0 / 025$ & $0 / 63$ & $11 / 34$ & $0 / 22$ & $0 / 000$ \\
\hline Conservation value & $-0 / 642$ & $0 / 19$ & $-0 / 58$ & $9 / 227$ & $0 / 290$ & $0 / 000$ \\
\hline visual value & $0 / 465$ & $0 / 025$ & $0 / 54$ & $10 / 32$ & $0 / 20$ & $0 / 000$ \\
\hline Social value & $0 / 23$ & $0 / 015$ & $0 / 12$ & $7 / 082$ & $0 / 44$ & $0 / 23$ \\
\hline
\end{tabular}

\section{Results}

In Persepolis Site Museum, the preservative, historical, visual and social value components were evaluated and analyzed as some part of different value components of historical monuments. To express the values, various techniques were used to create attractiveness, some of which were successful but some others were not. According to the results of evaluating these techniques among 400 visitors it might be said that the role of historical and visual values obtained desirable results to create attractiveness by applying the techniques. To express the preservative value, the applied techniques have worked average while they have been weak at expressing social values. Next, a significant relationship between the techniques were found in terms of expressing historical, visual, preservative and social values to create aesthetic value among visitors. In the initial hypothesis, the visitors' ages were assumed to have a significant relationship in creating this value but the results rejected it. Hence, age is not a factor to express aesthetic differences out of the applied techniques. The evaluation also indicated that the applied techniques of expressing historical and visual values had a direct relationship with the aesthetic value. It means that the information from the techniques is understandable for the audience. But the relationship between the preservative method and the aesthetic value is reverse. That is to say although preservative techniques have caused the monument to continue living, it has violated the aesthetic value. Therefore the relationship between social and aesthetic values is not significant and this shows the weakness of the complex at expressing the social values hidden in the monument by applying the techniques.

\section{Discussion}

The results of the study of Persepolis site museum show that analyzing value features in historical sites can be very effective in creating attraction. This means that historical authenticity does not play an important role per se, but different values of importance in order to reach the best method are very influential in expressing values. In answering the first question of the present study, it can be concluded that there were some flaws in this field. For instance, Persepolis complex has high social values, but the applied techniques have not been successful to represent this value and therefore the audiences have not been able to get an appropriate concept of this value. Or it can be said that notwithstanding the fact that conservation techniques have saved the physical body of the monument, aesthetice value has been corrupted and attraction has been neglected.

It may seem that conservation managment strategies have not been appropriate in this site with respect to the present values and applied techniques in social and conservational values.

In answering the second question of the present study, it can be mentioned that what still makes attraction in audiences of Persepolis is its historical values which are internal characteristics. Using value features analysis techniques in historical sites can pave the ground to devise managment conservation plans which has been absolutly emphasized on with respect to audience roles.

\section{Conclusion}

It generally seems that this monument has become attractive among visitors mainly due to being old and historic. 
Unfortunately, the applied techniques have not worked well to create attractiveness and it is weakness that is observed in the preservation of most Iranian monuments. In brief, it can be said that as Iran has many monuments which have a high potential of attracting tourists, investigating and analyzing the factors affecting the attractiveness from the viewpoints of the visitors and also trying to remove the deficiencies might make the tourism industry prosperous in Iran.

Although today it is tried to investigate this issue in historical sites, unfortunately as accurate specialist activities are not done in this field due to modern preservation approaches, numerous shortages and weaknesses are seen because in Iran, preservative approaches are still classic.

\section{References}

Amiryeganeh, H., \& Nafisi, N. (2003). Persepolice: A Memory of Achaemenian. Tehran: Khane Farhang va Honar Goya.

Avrami, E., Mason, R., and De La Torre, M., eds .(2000). Values and Heritage Conservation. Research Report. Los Angeles, the Getty Conservation Institute.

Ayala, H. (1998). Preface, In M.S. Ratchford (Ed.), TCR strategic alliance: Tourism-conservationresearch, A report from the Conference on Heritage Tourism for the Next Millennium (p.v), December 2-4 1998, Panama City, Panama.

Bandarin, F. (2005). Foreword. In D. Harrison \& M. Hitchcock (Eds.), The politics of World Heritage: Negotiating tourism and conservation (pp. v-vi). Clevedon, UK: Channel View Publications.

Deladelle,M. M. (2001). Musee de site et de reconsitution archeologique. ICOM International committee for Museum and Collections of Archaeology and History Study Srries, 9. 9-11,

Erturk ,N. (2006).A management model for archaeological site museum in Turkey, museum management and curatorship 21, 336-348.

Feilden, B. M., \& Jokilehto, J. (2003). Guidelines for the management of World Heritage sites. Translat By Susan Cheraghchi. Tehran: Cultural Heritage.

Fyall, A., \& Rakic, T. (2006). The future market forWorld Heritage sites. In A. Leask \& A. Fyall (Eds.), Managing World Heritage sites (pp. 159-175). Oxford, UK: Butterworth-Heinemann.\& Pedersen, A. (2002). Managing tourism at World Heritage sites: A practical manual for World Heritage site managers. Paris, France: UNESCO World Heritage Centre

Hall, M., \& McArthur, S. (1993). Heritage management: An introductory framework. In M. Hall \& S. McArthur (Eds.), Heritage management in New Zealand and Australia: Visitor management, interpretation, and marketing. Melbourne: Oxford University Press.

Hazen, H. (2009). Valuing natural heritage: park visitors' values related to World Heritage sites in the USA. Current Issues in Tourism , 12: 2, 165-181.

Heidari, F., \& Saatiean, R. (2011). A View in Museums. Isfahan. Cultural Heritage, Handicrafts and Tourism. Kanon Faregh Tahsilan Daneshgah Azad.

Hojjat, M. (2001). Cultural Heritage in Iran. Tehran: Cultural Heritage institue.

Huh, J., \& Uysal, M. (2004). Satisfaction with Cultural/Heritage Sites: Virginia Historic Triangle, Journal of Quality Assurance in Hospitality \& Tourism, 4:3-4, 177-194

Lowenthal, D. (2005). Natural and cultural heritage. International Journal of Heritage Studies, 11(1), 81-92.

Mason, R. (2002). Assessing the values of cultural heritage. Los Angless: Getty Conservation Institute.

Moscardo, G., Green, D., \& Greenwood, T. (2001). How great is the Great Barrier Reef! Tourists' knowledge and understanding of the World Heritage status of the Great Barrier Reef. Tourism Recreation Research, 26:1, 19-25.

Munos Vinos, S.(2005). contemporary theory of conservation, first published. Elsevier Butterworth Heinemann, Oxford London. P 2

Prentice, R. (1993). Tourism and heritage attractions. London and New York: Routledge.

Regidor, R. (2009). Impacts of music festivals on tourists' destination image and local community Case Study: Womad and Contempoprane Festivals in Extremadura (Spain): M.A. European Tourism Management, Bournemouth University.

Salehi, S., \& Hassanpour, M. (2012). Planning and development of tourism: Practical approach to planning and tourism marketing. Mazandaran: Nashre daneshgah.

Shiraziyan, R. (2013). Attraction in historical sites and Monuments. Tehran: Dastan.

Sun Hua, H. (2010) . World Heritage Classification and Related Issues-A Case Study of the "Convention Concerning the Protection of the World Cultural and Natural Heritage". Procedia Social and Behavioral Sciences , 2,6954-6961

Vestheim, G., Fitz, S., \& Foot, M.J.( 2001). Group report: Values and the artifact. In Rational Decision Making in the Preservation of cultural property ( N. S. Baer and F. Snickars, eds) pp, 211-222.

The Burra Charter .(1999- 2002 ). The Australia ICOMOS charter for Places of cultural significance. peter Marquis. Kyle.

The Nara Charter. (1994). The ICOMOS Charter for Autenthicity of Places.

Van Oosterzee, P. (2000). Ecotourism and biodiversity conservation - two way track. Pacific Conservation Biology, 6:2, 89-93.

YI WANG, Z., \& WEI CHEN. (2008). Aesthetic Values in Sustainable Tourism Development: A Case Study in Zhangjiajie National Park of Wuling Yuan, China, Journal of China Tourism Research, 4:205-218. 